\title{
航速測定,用計算機構に於ける摩擦圓盤裝置の精度 特に摩擦轉動輪の滑りと變形に就て
}

\author{
长”山男 \\ 摘 要
}

\begin{abstract}
本渝文は射擊指揮具に於ける航速測定に用ひらるる摩摖圓船裝置の精度を研究せるものにして 訆美をその原因より分類し機素誤差, 沮立誤差, 固有誤差とす (符2章)。機素, 組立兩誤差を. 理論的に考察しその大いさを實例に就き求めその補正法を考察す (第3，4 音). 斯の如き兩誤差 在除く为佮生ずる本質的なる固有誤差を實睑的に求めたり (第 5 章). 本誤差の檢討に當りては基 硶的なる二物體の接觸に依る變形の實踰より始め, 次で生じある固有滑りを實驗綕果より種々の

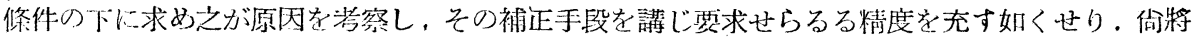
來新しき摩擦㵋盤裝置の設計に當り必要なる資料を述べたり。
\end{abstract}

目一次

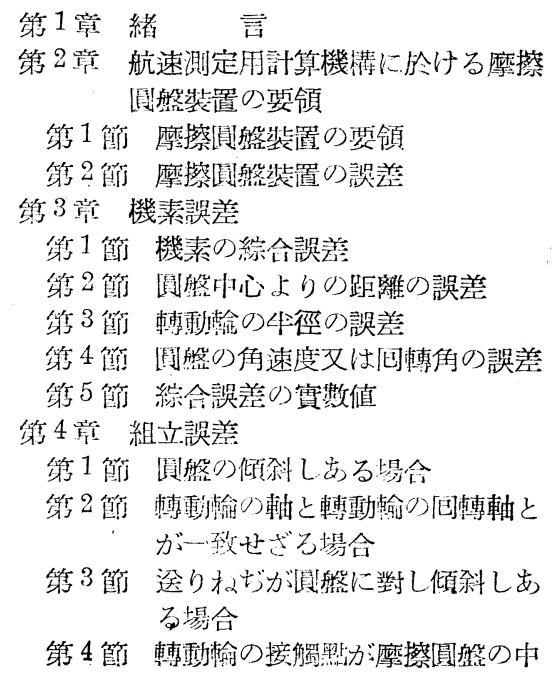

\section{第 1 章 緒 言}

對空射熬指挥具に於て航空测定老種續的且僢 間的に行ふの重要なるは今更言ふまでもない。

第一次世界大戰型の飛行秒時测定に依る航速 测定器を以てしては，航速の著しく增加したる 現航空目標の射擊は不可能と稱しても宜しん. されば現用指揮具にあつては殆んど航速測定裝 置を指揮具內に收容し之を自動化し，航速の瞬 間的な值を得るに努めて居る．之が䈆計算機構
心を通らざる場合

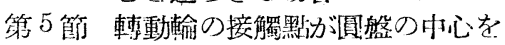
通るも，轉動輸はその軌跡と傾 きせる場合

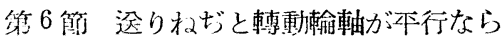
ざる場合

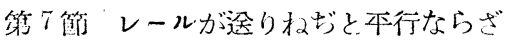
る場合

筷 8 節 機素誤差及組立誤差の總稱

绝 5 莘 固方誤差

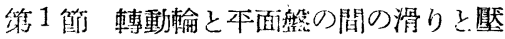
力とひ閣係

绾2節 轉動輸と本面艋の閩に於ける接

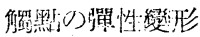

筧 3 節 轉動輪の滑り

第 4 節 結果の憸討及誤差の補证法

第 5 笁 珼地に於ける檜查

第6音 總括

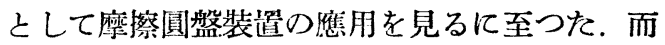
して兵器の精度, 運般性, 重量, 工作の難易又 は射慗目標の性質等に上り各國共自ら小じんま りした一定の大いさのもの設計し, 實用に供 して居る。

摩擦圆盤裝置は其他各種の計算機構汇廣く應 用を見るに至つてるるが，其の設計，製作に就 ては各研究者共確をる資料もなく，自らの關す る範湢內にて手探り的比必要と思はるる條件を 
定めてみるに過ぎないのが現㹜と思は れる。

本論文は標題に揭げる航速测定用裝 監に於ける本計算機構を檢討し，併世 て摩擦圓盤計算機構一般に對し, 設 計，製作の資料を與へんとするもので ある。

\section{第 2 章 航速測定用許算機構 に於ける摩擦圄盤装置の 要領}

第 1 贸 摩擦凅盤裝置の要領 摩擦圆盤裝埴 老使用せる航速計算機構の一例を示すと圖 1 の 如く先づ變位に比例せる囸轉角，郎航速に比例 せる触速度 $\omega^{\prime}$ と，定速にて回轉せる圆盤 $\mathrm{A} に$

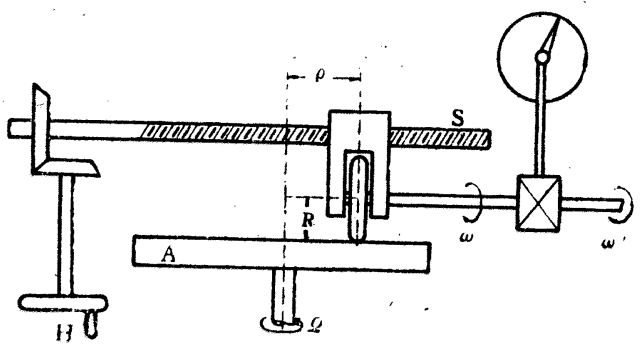

圖 1

依り驅動さるる摩擦轉動輸 B の角速度 $\omega$ とを 差動䓝車に位り加減し，その值を目盛板指針に 傳へる，今轉把 $\mathrm{H}$ を趔して轉動輪の位置を適 當にして $\omega$ と $\omega^{\prime}$ とを一致せしむるときは指針 靜止しその場合に於ける轉動輪の位置 $\rho$ は $\omega^{\prime}$ 郎航速に比例することとなる．尚更に自働化し た一例を示すと圖 2 の如く $\omega^{\prime}$ と $\omega$ を差動䪭車 にて加減し其の值 $\left(\omega^{\prime} \sim \omega\right)$ を直接揆りねぢ $\mathrm{S}$

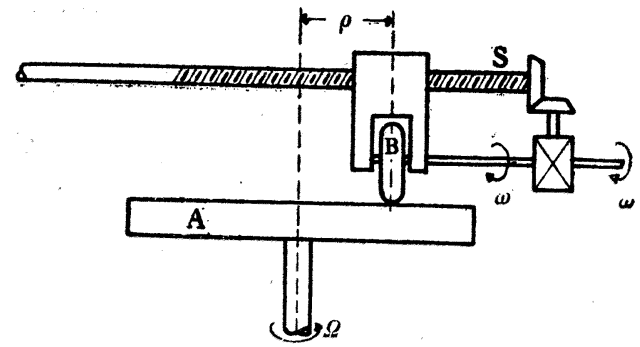

圈 2

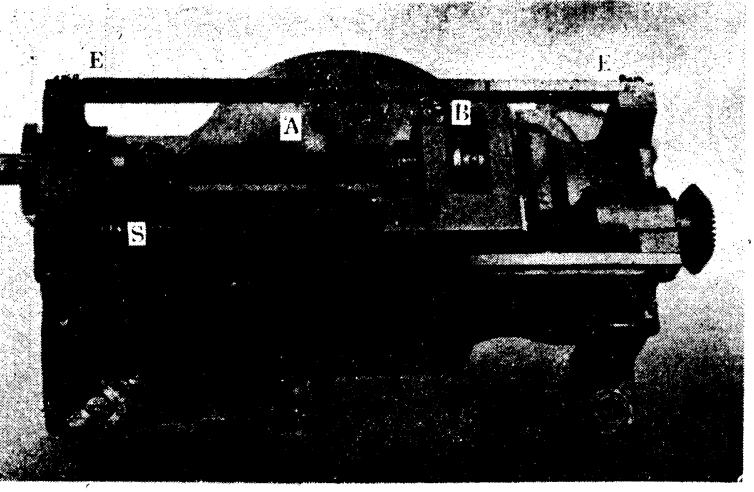

3

几僡へ轉動輸の位寘 $\rho$ を加減し $\omega=\omega^{\prime}$ なる位 置に至れば靜止する如くする。

圆 3 は摩擦圓盤裝置の鼠㯖であり，A は摩擦 圓盤にして原動機に依り驅動され定速回轉を行 ふ.B は摩擦轉動輸こして圆盤A几接觸し滑ら ボ，變形せずに包轉しつつ移動し得るＳは轉 動輸の送りねぢにして轉把 $\mathrm{H}$ を䞤せば轉動輪 B を圓盤上にてその直徑方向に移動せしむる。

$\mathrm{E}, \mathrm{E}$ は轉動輪の移動の案內レールである。

今摩擦圓盤の角速度を $Q$, 摩擦盤の中心上り 摩擦轉動輸の接觸點ま.での距離を $\rho$, 摩擦轉動 輸の角速度を $\omega$ ，その牛徑を $R$ とすれば, 理 想的な場合上して次り關係が成立する。

$$
\omega=\frac{\rho \Omega}{R}
$$

又之を回轉角の關係に改むれば

$$
\theta=\frac{\rho \Theta}{R}
$$

となる。但し $\Theta$ は摩擦圓盤の间轉角， $\theta$ はは轉動 輪の回轉角である、今圆盤 A は定速回轉を行ふ を以て $\boldsymbol{Q}$ は常數之荐へて考支へない。

郎式（1）を書き換へて $\rho=R \omega / \Omega$ とする時 $\Omega=$ const となる如く組立て得るに依り， $\rho$ の 大いさが所要の速度に比例するとととなる，依 つて $\Omega$ が一定の時の $\rho, R, \omega$ の關係老研究せ ば摩擦圆盤裝置の精度を決定し得るのである。

第 2 節 摩擦圆盤装覆の精度及諤差 摩祭圓 盤裴置に依り計算を行ふ場合起り得べき誤差は 
前述の如く $\rho, R, \omega$ (又は $\theta$ ) の關係に基く子 のにて次の三つに區分して考へ得る.
A 機溸誤差,
B 組立誤差,
C 固有誤差,

A は計算機の構成機素の工作不正积に依るも のにて精密工作の限度が問題となる.

B は之等機素を如何に組立調整するかに係る ものにして, 例へば摩摖圓盤と揆りねぢとが本 行にあらずとか，轉動輪が摩擦圆盤に垂直なら ずとか，又はその中心を通過せずとか等であり 仕上及組立技術の向上に依り減少し得る。

$\mathbf{C}$ は $\mathbf{A}, \mathbf{B}$ の誤荠を除くも向依然として殘る ものにて，摩擦による運動現像そのものによる 誤差であつて，轉動輪之圆盤之が點接觸をせす。 面接罶をするととを芳へねばならね基礎的なる のである．故に本䃑究に於ては順序として機素 哭崖, 組立誤差の一般式を求め, 實例们就をそ の大いさを吟味し最後の固有誤考に關しては特 几基礎的實驗上り始め，摩擦圆盤裝犆の苗用性 如何を觀察し，かかる計算機構一般への示唆を 提供せんとするものである。

\section{第3 章 機素誤差}

第 1 節 機素の綜合誤差. 機構要領にて述べ し如く摩擦圓盤裝置に於て (1) 及 $\left(1^{\prime}\right)$ の關 係が成立する，郎

$$
\omega=\frac{\rho \boldsymbol{\Omega}}{h} \quad \text { 或は } \quad \theta=\frac{\rho \Theta}{R}
$$

となる。今規定值に對する $\rho, R, \Omega$ の誤美を夫 « $\Delta \rho, \Delta R, \Delta \Omega$ とすれば, 個々の誤差の值か ら生ずる $\omega$ の誤荎 $\Delta \omega$ は

$$
\frac{\Delta \omega}{\omega}=\frac{\Delta \rho}{\rho}+\frac{\Delta \Omega}{\Omega}-\frac{\Delta R}{R}
$$

にて與へらるるも， $\Delta \rho, \Delta R, \Delta \Omega$ 等を多數の個 くの誤差の平均的なる意味に解すれば，

$$
\frac{\Delta \omega}{\omega}=\sqrt{\left(\frac{\Delta \rho}{\rho}\right)^{2}+\left(\frac{\Delta \Omega}{\Omega}\right)^{2}+\left(\frac{\Delta R}{R}\right)^{2}}
$$

にて與へらる. 故に誤䅈なき $\omega$ を書き, 一般の誤差ある值を單に $\omega$ と記せば，

$$
\omega=\omega,+\Delta \omega=\omega \cdot\left(1+\frac{\Delta \omega}{\omega_{o}}\right) \equiv \omega \cdot(1+\varepsilon)
$$

となり，補正項 $\varepsilon$ は (3) に等しい. 次に $\Delta, \Delta R, \Delta \Omega$ に就て夫々檢討する.

第 2 蒠 圆盤中心よりの距離の誤差 $(\Delta \rho)$ 揆 りねぢ S(雄ねぢ) は頂角 $29^{\circ}$, 步み $2 \mathrm{~mm} の$ 梯形ねぢにて極めて精密に加工してある。乙れ には勿論 Lindner 製ねぢ研腰盤の如きはの

\begin{tabular}{|c|c|c|c|}
\hline & 䊈呼寸法 & 害測寸法 & 誤 差 \\
\hline$t_{1}$ & $0.740 \mathrm{~mm}$ & $0.735 \mathrm{~mm}$ & $-5 \mu$ \\
\hline$t_{2}$ & $0.610 \mathrm{~mm}$ & $0.590 \mathrm{~mm}$ & $-20 \mu$ \\
\hline$H$ & $1.250 \mathrm{~mm}$ & $1.300 \mathrm{~mm}$ & $+50 \mu$ \\
\hline$h_{1}$ & $0.500 \mathrm{~mm}$ & $0.510 \mathrm{~mm}$ & $+10 \mu$ \\
\hline$h_{2}$ & $0.750 \mathrm{~mm}$ & $0.790 \mathrm{~mm}$ & $+40 \mu$ \\
\hline$L \frac{\alpha}{2}$ & $14^{\circ} 30^{\prime}$ & $14^{\circ} 28^{\prime}$ & $-2^{\prime}$ \\
\hline$R \frac{\alpha}{2}$ & $14^{\circ} 30^{\prime}$ & $14^{\circ} 34^{\prime}$ & $+4^{\prime}$ \\
\hline
\end{tabular}
て仕上げるのである。乙れの諸寸法を圖 4 亿示 す.

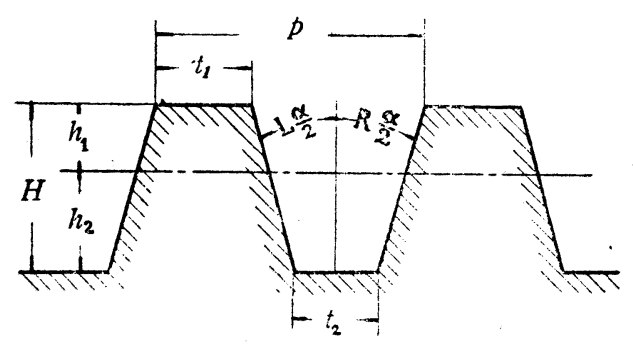

\section{圆 4}

計算機構として最も大切なる誤老は步みの誤 差である。 今原點より $i$ 番目の步みに $\Delta \rho_{i}$ だ けの諤老があれば，步みは $2 \mathrm{~mm}$ であるから 原點から此の $i$ 番目の步みの終の點に至る距離 は $\rho=2 i \mathrm{~mm}$ であり, そてまでの累計誤差は $\Delta \rho=\sum_{i=1}^{i} \Delta \rho_{i}$ となり, $\Delta \rho / \rho$ が知れる.表 1 亿 この $\Delta \rho_{i}, \Delta \rho, \Delta \rho / \rho$ の實測值の一例を示す. 圖 5 はての $\Delta \rho / \rho を \rho$ に對して描いたるのであ る.

$\rho$ の大なる處にては $\Delta \rho / \rho$ は $10 \times 10^{-5}$ とす 


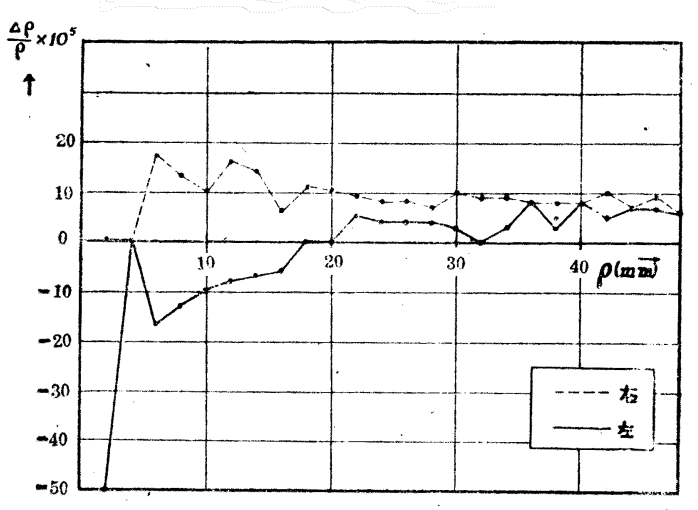

四 5

\begin{tabular}{r|rrr|rrr}
\hline \hline & \multicolumn{3}{|c|}{ 左 } & \multicolumn{3}{|c}{ 在 } \\
\cline { 2 - 6 } & $\Delta \rho i(\mu)$ & $\Delta \rho(\mu)$ & $\Delta \rho / \rho \times 10^{5}$ & $\left.\Delta \rho_{i}{ }^{\prime} \mu\right)$ & $\Delta(\mu)$ & $\Delta \rho / \rho \times 10^{5}$ \\
\hline 1 & -1 & -1 & -50 & 0 & 0 & 0 \\
2 & 1 & 0 & 0 & 0 & 0 & 0 \\
3 & -1 & -1 & -17 & 1 & 1 & 17 \\
4 & 0 & -1 & -13 & 0 & 3 & 13 \\
5 & 0 & -1 & -10 & 0 & 1 & 10 \\
6 & 0 & -1 & -8 & 1 & 2 & 16 \\
7 & 0 & -1 & -7 & 0 & 2 & 14 \\
8 & 0 & -1 & -6 & -1 & 1 & 6 \\
9 & 1 & 0 & 0 & 1 & 2 & 11 \\
10 & 0 & 0 & 0 & 0 & 2 & 10 \\
11 & 1 & 1 & 5 & 0 & 2 & 9 \\
12 & 0 & 1 & 4 & 0 & 2 & 8 \\
13 & 0 & 1 & 4 & 0 & 2 & 8 \\
14 & 0 & 1 & 4 & 0 & 2 & 7 \\
15 & 0 & 1 & 3 & 1 & 3 & 10 \\
16 & -1 & 0 & 0 & 0 & 3 & 9 \\
17 & 1 & 1 & 3 & 0 & 3 & 9 \\
18 & 2 & 3 & 8 & 0 & 3 & 8 \\
19 & -2 & 1 & 3 & 0 & 3 & 8 \\
20 & 2 & 3 & 8 & 0 & 3 & 8 \\
21 & -1 & 2 & 5 & 1 & 4 & 10 \\
22 & 1 & 3 & 7 & -1 & 3 & 7 \\
23 & 0 & 3 & 7 & 1 & 2 & 4 \\
24 & 0 & 3 & 6 & 1 & 3 & 6 \\
\hline
\end{tabular}

蕙 1 .

れば充分であらう。然しのの小なる處にては必 すしも斯の如くならす，若し最初の步みに於て $1 \mu$ の誤差があれば $0.001 / 2=0.0005$ となる. 而して $1 \mu$ の誤差の起る確率はてのねぢに於 ては略々 0.3 である. 故に以後 $\Delta \rho / \rho$ は大なり とも 0.0005 普通は 0.0001 と考へるとととす 万.

次に轉動輪を支持する框に含まれる雌ねら゙に
就て逊べる．之は研磨仕上を終へた雄ねぢ S に堅く嵌合する如く雌ねぢをタップ仕上をな し，圖6に示す A の部分を雄ねぢに嵌合せ

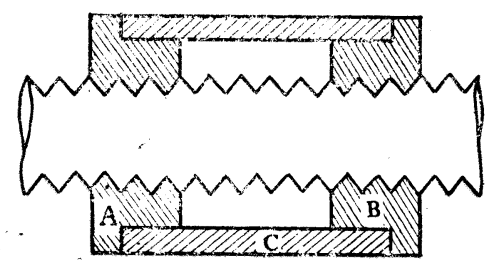

圖 6

しめ, 更に A に C 老取付ける。次に B t雄 ねぢに精密㟶合する如く替合せを行ひ，Cの取 付を州減する，摆合せは種油に極少量ラッピン グ劑を韲じたるものにより行ひ，後數回の洗滌 を行ひ，次で種油のみにて數十回往復運動をな さしめ完全なる嵌合を行ふ。斯のくして得た雌 雄ねぢの組合せは望用上完全に背㗂を除き得 る.

第 3 節 轉動輪の牛徑の誤差 $(\Delta R)$ 轉動輪は 研磨及ラッピング仕上に上り $0.005 \mathrm{~mm}$ 以內の 偏心に約め得る. 故に $R=11 \mathrm{~mm}$ のとき $\Delta R / R$ は最大 $0.005 / 11=0.0004$ となる。瓷際の例に 就き見れば，一つの轉動輪の半徑を多數個所に て测定すれば, $R$ の公算誤差は $0.001 \mathrm{~mm}$ 程度 である。

第 4 節 摩擦圓盤の角速度又は司轉角の誤差 $(\Delta \Omega$ 又は $\Delta \Theta$ ). ばね驅動の場合に於ては $\Delta \Omega / \Omega$ を 0.0032 までに納め得る。更に精密を要する ときははフォニック・モータを使ふ。

又後に述べる固有誤差の實驗に於ては $\left(1^{\prime}\right)$ の式を使ふ. 且機素誤差, 組立誤差の除去又は 補正に努める。乙の場合には $\Theta=360^{\circ}$ であ り， $\Theta$ は $1^{\circ}$ の目盛をした圆盤で测定するが， 裝置の都合上 $\Delta \Theta$ は $0.2^{\circ}$ 位である. 從つて

$$
\Delta \Theta / \Theta=0.2 / 360=0.0006
$$
となる。

第 5 節 綜合誤差の賽數值 以上の各誤差を 綜合すれば，

$$
\Delta \rho / \rho=0.0001 \sim 0.0005,
$$




$$
\begin{aligned}
\Delta R / R & =0.0005, \\
\Delta \Omega / \Omega & =0.0032, \quad \Delta \Theta / \Theta=0.0006
\end{aligned}
$$

である故，綜合した值は（3）に依り計算して

1） $\Delta \Omega / \Omega$ を使ふ場合には： $\Delta \omega / \omega=0.0033$

2） $\Delta \Theta / \Theta$ を使ひ, $\Delta \rho / \rho=0.0005$ とすれば:

$$
\Delta \theta / \theta=0.0009
$$

3） $\Delta \Theta / \Theta$ を使ひ, $\Delta \rho / \rho=0.0001$ とすれば;

$$
\Delta \theta^{\prime} \theta=0.0008
$$

となる。

但し注意すべきは，調整後の使用中に於ける $\Omega$ の變化は上に示した $\Delta \Omega$ の值よりも遥に小で あり計算逐行中には $\Omega$ は略々一定と考入得るて とである. 從つて後に第 4 章, 第 8 節に述べる 如く $\Delta \omega / \omega$ の誤至を補正した後には上に示した 樣な程度の誤莹が起るのではない。

\section{第 4 章 組立誤差}

精密工作特に優秀なる精密測定器を有する現 狀にては機素誤差に就ては解沃に左程困難を感
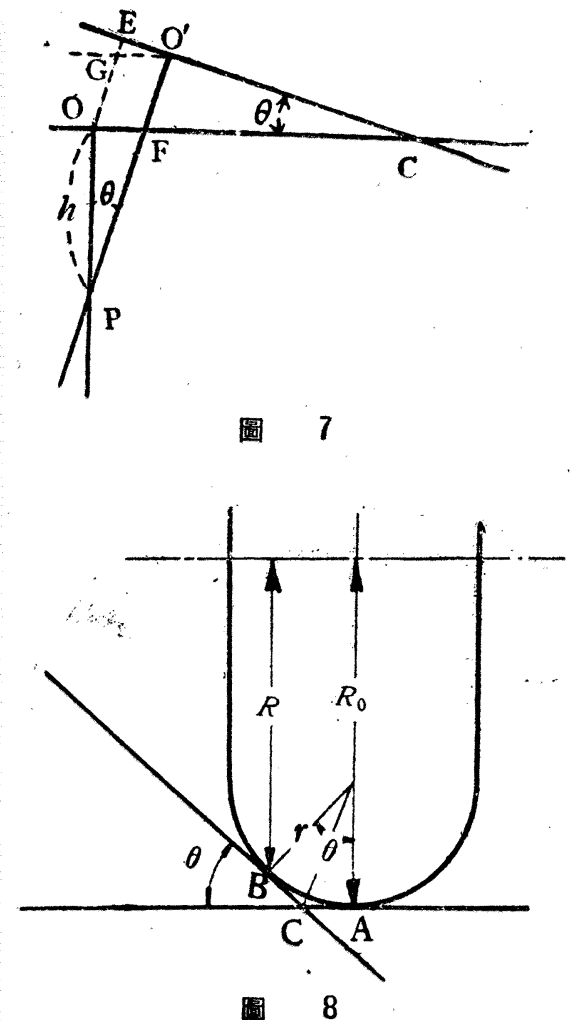

じないが, 組立は仕上工の訓練と技倆とに期待 する關係上，豫め各場合の誤考を研究調查し置 レて工員走指導するを要する，故に次に實際作 紐に於て起り得べ場合に就き檢討して見や 5 .

第 1 節 圆盤の傾斜しある場合，摩擦圓盤が

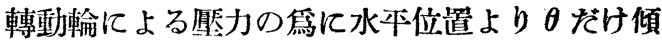
々て居るとすれば轉動輪の接觸點は圖 8 て於て AよりBに移り盤の中心は圖 7 に於て $\mathrm{O}$ より $\mathrm{O}^{\prime}$ 几移る。

今 $O A=\rho_{\prime}, \quad O^{\prime} B=\rho$ とすれば $\rho=O^{\prime} B=O^{\prime} C-B C$,

しかるに

$O^{\prime} C=C E-O^{\prime} E=O C \cdot \cos \theta-h \tan \theta \cos \theta$

. $\left(\because O^{\prime} E=O^{\prime} G \cos \theta=O F \cos \theta=h \tan \theta \cos \theta\right)$, 又 $O C=O A-A C=\rho_{0}-r \tan (\theta / 2)$, だから

$O^{\prime} C=\left\{\rho_{0}-r \tan (\theta / 2)\right\} \cos \theta-h \tan \theta \cos \theta$, $\therefore \rho=\rho_{0} \cos \theta-r \cos \theta \tan (\Omega / 2)-h \sin \theta-r \times$ $\tan (\theta / 2) \cdot \sin \theta, \cos \theta, \tan (\theta / 2)$ を展開し $\theta^{2}$ の 項まで探ると

$$
\begin{aligned}
\rho & =\rho_{0}\left(1-\frac{\theta^{2}}{2}\right)-r\left(1-\frac{\theta^{2}}{2}\right) \frac{\theta}{2}-h \theta-r \frac{\theta}{2} \\
& =\rho_{o}-\frac{\rho_{o}}{2} \theta^{2}-\frac{r}{2} \theta-h \theta-\frac{r}{2} \theta \\
& =\rho_{o}-(r+h) \theta-\frac{\rho_{o}}{2} \theta^{2} .
\end{aligned}
$$

次に轉動輪の徑の方は

$$
\begin{aligned}
R & =R_{o}-(r-r \cos \theta)=R_{,}-r(1-\cos \theta) \\
& =R_{3}-\frac{r}{2} \theta^{2} .
\end{aligned}
$$

故に之等を基本の 式(1) に入れれば，

$$
\begin{aligned}
\omega & =\frac{\Omega}{R} \rho=\Omega \frac{\rho_{o}-(r+h) \theta-\frac{\rho_{o}}{2} \theta^{2}}{R,-\frac{r}{2} \theta^{2}} \\
& =\Omega\left\{\rho_{o}-(r+h) \theta-\frac{\rho_{o}}{2} \theta^{2}\right\}\left(R_{o}-\frac{r}{2} \theta^{2}\right)^{-1}
\end{aligned}
$$


然るれ $\left(R_{0}-\frac{r}{2} \theta^{2}\right)^{-1} \fallingdotseq R_{0}^{-1}\left(1+\frac{r}{2 R_{0}} \theta^{2}\right)$. $\therefore \omega \fallingdotseq \Omega\left\{\rho_{0}-(r+h) \theta-\frac{\rho_{0}}{2 R_{0}^{2}}\right\}\left\{\frac{1}{R_{0}}+\frac{r}{\partial R_{0}^{2}} \theta^{2}\right\}$

$$
\begin{array}{r}
=\Omega\left\{\frac{\rho_{0}}{R_{0}}-\frac{r+h}{R_{0}} \theta-\frac{\rho_{0}}{2 R_{0}} \theta^{2}\right. \\
\left.+\frac{r \rho_{0}}{2 R_{0}^{2}} \theta^{2}+\cdots\right\}
\end{array}
$$

$$
\begin{aligned}
& =\frac{\Omega \rho_{0}}{R_{0}}-\frac{\Omega}{R_{0}}(r+h) \theta-\frac{\Omega \rho_{0}}{2 R_{0}{ }^{2}}\left(R_{0}-r\right) \theta^{2} \\
& =\omega_{0}\left\{1-\frac{r+h}{\rho_{0}} \theta-\frac{R_{0}-r}{2 R_{0}} \theta^{2}\right\} \\
& =\omega_{0}(1-\varepsilon) .
\end{aligned}
$$

[但し $\omega_{0}=\frac{\Omega_{\rho_{0}}}{R_{0}}$ とする $]$

故に負値の誤差を生ず。

圓盤の傾斜が圖 7 に示すもの之逆になつて居 る場合には,上と同樣に計算して次の如くなる。

$$
\omega=\omega_{0}\left\{1+\frac{r+h}{\rho_{0}} \theta-\frac{R_{0}-r}{2 R_{0}} \theta^{2}\right\} .
$$

次に $\rho_{0}$ により $\theta$ が如何に變るかは摩擦圓盤 の軸の支へ力が稍複雜であるから，計算により 正碓に出すことは困難である。乙视故摩擦圆盤

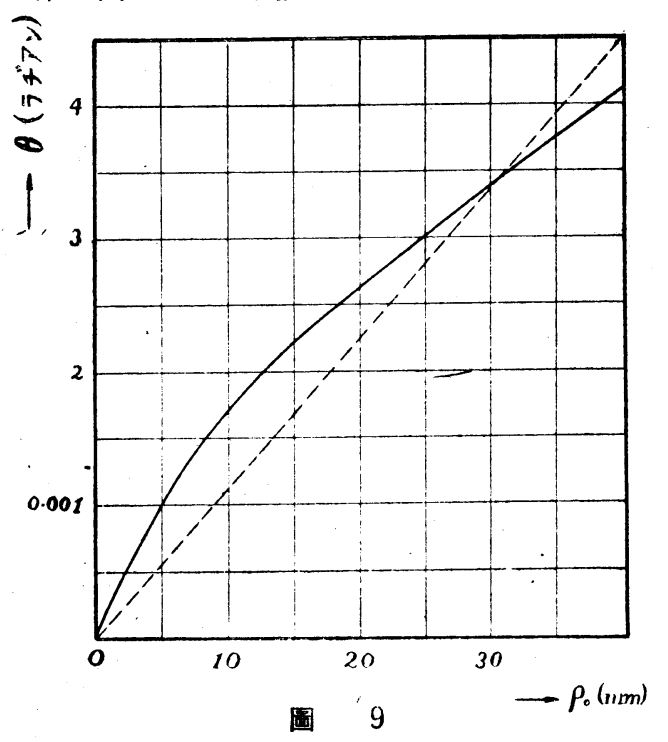

の緣に測定器のスピンドルをあて轉動輪により 荷重の㲘つた狀態で垂道の變位をを测定し，てれ より $\theta$ を算出すれば圖 9 の如くなる。乙れを近 似的に通線（圖 9 几示寸點線）と見做せば

$$
\frac{\theta}{\rho_{0}}=\frac{4 \cdot 5}{4000} \mathrm{radian} / \mathrm{mm} \text {, }
$$

この關係を使へば，實例に就ては

$$
h=18.5 \mathrm{~mm}, r=1.5 \mathrm{~mm}, R_{0}=13.0 \mathrm{~mm}
$$
なる故に，

$$
\varepsilon=\frac{r+h}{\rho} \theta=0.0023 \fallingdotseq \frac{2}{1000}
$$

となる。乙の影響は小なりとは言へ無視するて と出來ない，但し之は後に述べる如、轉動陯の 徑党僅に減ずることに依り補正出來る。

\section{第 2 節轉動輪の軸と轉動輪の回轉軸とが二} 致せざる場合. 圖 10 亿示す如く摩擦轉動陯 の包轉軸と轉動輸自身の軸とが一致せぬ時は轉 動輸は獨樂の運動を行ひ首振り運動を篇す。

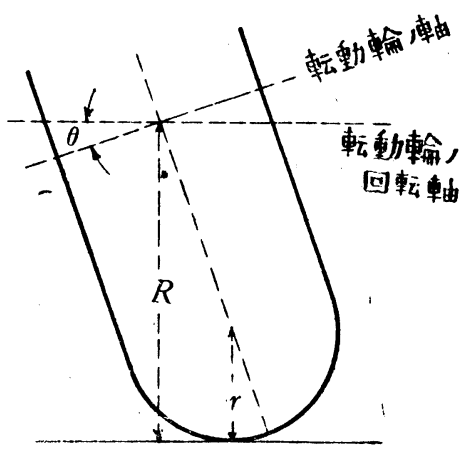

圆 10

ての場合誤差なき $\rho, R$ を $\rho_{0}, \kappa_{0}$ とすれ ば

$$
\begin{aligned}
\rho & =\rho_{0}+\left(R_{0}-r\right) \sin \theta \\
& \fallingdotseq \rho_{0}\left\{1+\frac{R_{0}-r}{\rho_{0}} \theta\right\}, \\
R & =\left(R_{0}-r\right) \cos \theta+r \\
& \fallingdotseq R_{0}-\left(R_{0}-r\right) \frac{\theta^{2}}{2}
\end{aligned}
$$

となる。然るに $\theta$ は時閅的に一定にあらすして $\theta=\theta_{\text {max }} \sin \varphi$ 
の如く變化す．故に $\omega$ を求める烝には此の $\varphi$ に 關して本均を取るを必要とす。即ち

$$
\begin{aligned}
\omega= & \frac{1}{2 \pi} \int_{0}^{2 \pi} \frac{\Omega_{\rho}}{R} d \varphi \\
= & \frac{1}{2 \pi} \int_{0}^{2 \pi} \frac{\Omega_{\rho_{0}}\left\{1+\frac{R_{0}-r}{\rho_{0}} \theta\right\}}{R_{0}\left\{1-\frac{R_{0}-r}{2 R_{0}} \theta^{2}\right\}} d \varphi \\
\fallingdotseq & \frac{\omega_{0}}{2 \pi} \int_{0}^{2 \pi}\left\{1+\frac{R_{0}-r}{\rho_{0}} \theta+\frac{1}{2}\left(1-\frac{r}{R_{0}}\right) \theta^{2}\right\} d \varphi \\
= & \frac{\omega_{0}}{2 \pi} \int_{0}^{2 \pi}\left\{1+\frac{R_{0}-r}{\rho_{0}} \theta_{m a t} \sin \varphi+\frac{1}{2}\right. \\
& \left.\times\left(1-\frac{r}{R_{0}}\right) \theta^{2}{ }_{m a t} \sin ^{2} \varphi\right\} d \varphi .
\end{aligned}
$$

然るに $\int_{0}^{2 \pi} \sin \varphi d \varphi=0, \int_{0}^{2 \pi} \sin ^{2} \varphi=\pi$

・なる故

$$
\begin{aligned}
\omega & =\frac{\omega_{0}}{2 \pi}\left\{2 \pi+\frac{\pi}{2}\left(1-\frac{r}{R_{0}}\right) \theta_{m(t x .}^{2}\right\} \\
& =\omega_{0}\left\{1+\frac{1}{4}\left(1-\frac{r}{R_{0}}\right) \theta^{2}{ }_{m, x x}\right\} \cdots
\end{aligned}
$$

となる。测定の結果 $\theta_{m a:}=1 \cdot 5 / 1000$ radian, $R_{0}=11 \mathrm{~mm}, r=1.5 \mathrm{~mm}$ であるから

$$
\omega=\omega_{0}\left(1+4.86 \times 10^{-7}\right)
$$

となり，我くの取扱ふ量は $10^{-4}$ 以內交るに依 り省略可能である。

第3 節 送りねちかが圓盤に對して傾斜しある

場合 摩擦轉動輸の位置により盤は上下するも

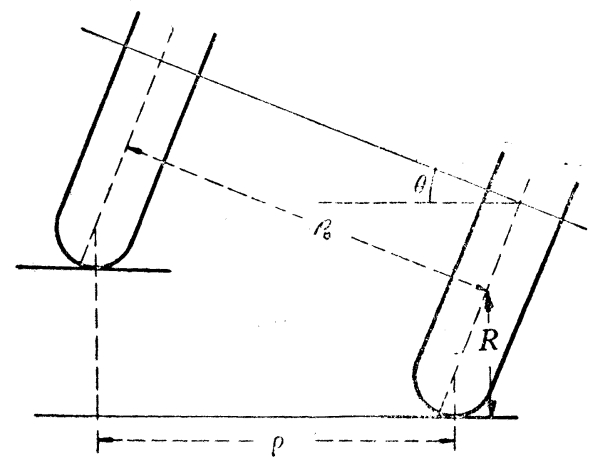

圖 11
此の變位は影響せず次の如く考へらる。

$$
\begin{aligned}
\rho & =\rho_{0} \cos \theta \doteqdot \rho_{0}\left(1-\frac{\theta^{2}}{2}\right), \\
R & =\left(R_{0}-r\right)+r \cos \theta \fallingdotseq R_{0}-r \frac{\theta^{2}}{2}, \\
\therefore \omega & =\frac{\Omega_{3}}{R}=\frac{\Omega_{0}\left(1-\frac{\theta^{2}}{2}\right)}{R_{0}-r \frac{\theta^{2}}{2}} \\
& =\omega_{\nu} \frac{1-\frac{\theta^{2}}{2}}{1-\frac{r}{R_{0}}-\frac{\theta^{2}}{2}} \\
& =\omega_{0}\left(1-\frac{\theta^{2}}{2}+\frac{r}{R_{0}} \frac{\theta^{2}}{2}\right) \\
& =\omega_{0}\left\{1-\frac{1}{2}\left(1-\frac{r}{R_{0}}\right) \theta^{2}\right\} \cdots(6)
\end{aligned}
$$

然るに $r=1.5 \mathrm{~mm}, R_{0}=11 \mathrm{~mm}$, 今 $\theta=1 / 200$ radian とせば

$$
\omega=\omega_{0}\left(1-1 \cdot 1 \times 10^{-5}\right)
$$

となり省略可能である.

第 4 節 轉動輪の接觸點が摩擦圓盤の中心を 通らざる場合，圖 12 亿於て接觸點の軦跡を $A$ $B$, 盤の中心を $O$ とすれば

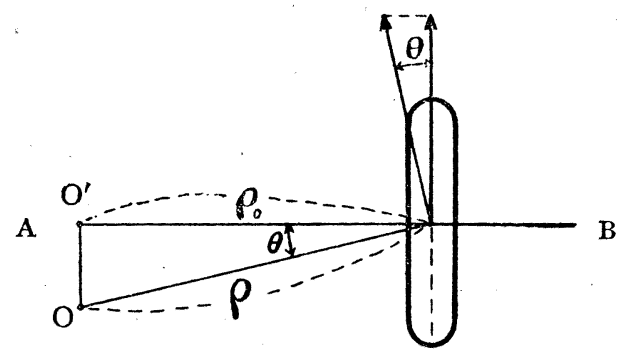

$$
O P=\rho, \quad \begin{gathered}
\text { 圖 } \\
O P
\end{gathered}
$$

であり, 從つて

$$
\omega=\frac{\Omega \rho}{R} \cos \theta=\frac{\Omega \rho_{0}}{R} \cdots(7)=
$$

となり誤差は生起せず, 即 $P$ に於ける接觸が 點接觸なる限り中心よりはづるるも差支なし． 


\section{第 5 節 轉動輪の接觸點が圄盤の中心を通過} するも，轉動輪はその軌跡と傾きある場合 こ の場合圖より明かなる如く

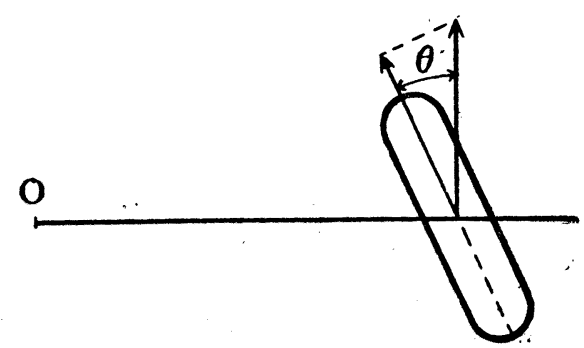

$$
\begin{gathered}
13 \\
\omega=\frac{\Omega \rho}{R} \cos \theta=\omega_{0} \cos \theta \\
=\omega_{0}\left(1-\frac{\theta^{2}}{2}\right) \cdots \ldots \ldots
\end{gathered}
$$

然るに $\theta$ は $\mathrm{I} / 1000$ 乃至 $2 / 1000$ をるを以て此 の誤差は省略可能なり.

\section{第 6 節 送りねぢと轉動輪軸が平行ならざる}

場合 揆りねぢ，轉動輪軸は共に摩擦圓盤に對 して平行なりとするも，轉動輪軸の取付不良に て平面內に於て揆り将ぢに對し傾きある場合， 或はねぢの取付不良の場合も起り得.

今圖 14 に示す如く $\phi, \theta$ を取れば

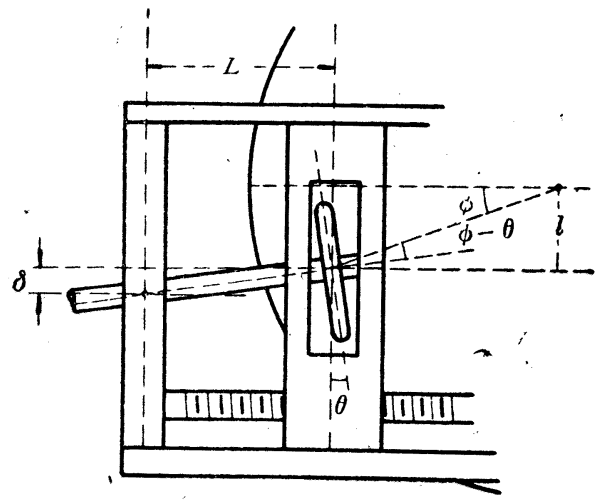

圆 14

$$
\begin{aligned}
\omega & =\frac{\Omega \rho_{0}}{R} \cos (\phi-\theta)=\frac{\Omega 0_{0} \cos (\phi-\theta)}{\cos \phi} \\
: \omega & =\omega_{0}(\cos \theta+\sin \theta \tan \phi) \cdots \cdots(9) .
\end{aligned}
$$

$\theta, \phi$ の值は轉動輪の位置により變化するも， $\theta$ の最大は圖 14 亿於て轉動輪が盤の最左端に移 りし場合にて, $L=30 \mathrm{~mm}, \delta$ は最大 $0.01 \mathrm{~mm}$ とすれば

$$
\tan \theta=0.01 / 30=0.00033 .
$$

乙の㭙 $\rho_{0}=40 \mathrm{~mm}$ である. $\tan \theta=0.00033$ の如き $\theta$ に於ては $\tan \theta=\theta=\sin \theta, \cos \theta=1$ と見做し得るを以て

$$
\omega=\omega_{0}(1+0.0003 \tan \varphi) .
$$

乙の修正項を有效數字の最後の桁郎ち $10^{-4}$ に 響かす篇には $\tan \varphi=1 / 3$ の時より小なる $\rho_{0} の$ 場合にしてその位㨁郎ち $\rho_{0}^{\prime}$ の值は $\tan \phi=1 / 3$ $=l / \rho_{0}^{\prime}$ 即ち

$$
\rho_{0}^{\prime}=3 l
$$

となる.故に $l$ の值を最大 $0.1 \mathrm{~mm}$ とするも $\rho_{0}$ $>0.3 \mathrm{~mm}$ の處にては省略可能である. 又實驗 の紹果に低れば $\omega$ は中心附近に於ては相當誤 厓を出すも，それは此の誤差のみに依らざるば 勿論である。

第7節 レールが送りねちと平行ならざる場 合レールが邆りねぢと篇す触を $\theta$ とすれば， ねぢの步みを $p$ 小ぢとレールとの間の間隔を

とすれば實際の步みは

$$
\begin{aligned}
& p=p_{0}+\frac{p_{0} \theta}{l} \\
& \therefore \omega=\frac{\Omega n p}{R}=\frac{\Omega n p_{0}}{R}\left(1+\frac{\theta}{l}\right)=\omega_{0}\left(1+\frac{\theta}{l}\right)
\end{aligned}
$$

なりと考へらる。兩方のレールを考ふる時には 何れか一方レールとして働きある方に就き上の 値を探れば宜しい．网方のレールが働く場合に はレールとレールとの間の傾角を $\varphi$ とし, 間隔 をdとすれば

$$
p=p_{0}+\varphi \frac{p_{0}}{d} .
$$

$$
\begin{array}{r}
\therefore \omega=\frac{\Omega n p}{R}=\frac{\Omega n p_{0}}{R}\left(1+\frac{\phi}{d}\right)=\omega_{0} \\
\quad \times\left(1+\frac{\phi}{d}\right) . \ldots
\end{array}
$$


となる。

レールの有效全長 $125 \mathrm{~mm}$ 几對し過大に見積 り $0.1 \mathrm{~mm}$ だけ兩端に於る間隔が違へりとする 8 $\tan \theta \div \theta=0 \cdot 1 / 125=0.00080$ 郎ち $2^{\prime} 45^{\prime \prime}$.

$l$ は $16 \mathrm{~mm}$ 又は $13 \mathrm{~mm}$ なるを以て小なる 方にては

$$
\omega=\omega_{0}(1+0 \cdot 000,062)
$$

となり全く省略し得る。他の場合は之以上なる を以て勿諭省略可能である。

第 8 節 機素誤差及組立誤差の總括 以上の 機装誤疼, 組立誤差至總括すれば, 誤差を $\omega=$ $\omega_{0}(1+\varepsilon)$ の形に表はすとき，次の如くなる。

I) 機素誤厓 $\varepsilon_{1}=0.003,3$ 又は $0 \cdot 000,9$

II) 組立誤差 1) $\varepsilon_{2}=-0.002,3$

2) $\varepsilon_{3}=0 \cdot 000,000,49$

3) $\varepsilon_{4}=-0 \cdot 000,011$

4) $\varepsilon_{5}=0$

5) $\varepsilon_{6}=0.000,002$ (最高)

6) $\varepsilon_{7}=0 \cdot 000,030($ 但 $L=$

$1 \mathrm{~mm}$ として)

7) $\varepsilon_{8}=0 \cdot 000,062$.

以上の誤差が皆同時に生ずる時の誤容は $\varepsilon=$ $\sqrt{ } \sum_{2} \varepsilon^{2}$ てて與へらる。机示す数值を入れれ ば

$$
\begin{array}{ll}
\varepsilon_{1}=0.003,3 \text { の時 } & 3=4.0 \times 10^{-3} \\
\varepsilon_{1}=0.000,9 \text { の時 } & \varepsilon=2.5 \times 10^{-3}
\end{array}
$$

となる、之等兩方の值はそのほとんど全部が (I) の $\varepsilon_{1}$ 之 (II) の 1)の $\varepsilon_{2}$ の寄與する處で ある. 然るに $\omega=\omega_{0}(1+\varepsilon)$ の形に書き得る場 合に $\varepsilon$ が $\rho, \Omega$ 等の值に依ら秀一定のものであ れば

$$
\omega_{0}(1+\varepsilon)=\frac{\rho_{0} \Omega_{0}}{R_{0}}(1+\varepsilon)=\frac{\rho_{0} \Omega_{0}}{l_{i}^{\prime}}
$$

となる如き $h^{\prime}$ に轉動輸の徑を選べば誤差は無

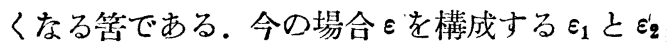
は先に述べを如く使用中略々一定之見做し得る から，上に求めたには大部分補正されるのであ る。

一方要求せられる精度は(第 5 章第 4 節參照) $2 \cdot 5 \times 10^{-3}$ であるが，乙の機素誤美，組古誤美の 和を補正したものに，次に述べる固有誤姜を併 せを值が，乙の要求せられる精度內にあるてと は後に示す通りであつて，以上の補正法つ有効 なととが知られる。

然し $\varepsilon_{1}, \varepsilon_{2}$ は減じ得れば刎諭良いのである。 即 $\varepsilon_{1}$ はばねに代ふるにフォニック・モータを 以てし， $\varepsilon_{2}$ は後に运べる如く圓盤の軸を長くし 支持法を適當に改めることに依り遞減し得るの である。（續く）

\section{Russell 水力送り複式砲彈のこぎり機}

Leicester, Bath Lane にある.S. Russell and Sons,.Ltd. では最近同商會の標淮水力送 り高速度常溫のてぎり機を下圖に示す樣な機械化進步改造した。それは錹造された歾彈の 開いた端部を一度に2つ切る営に特殊の設計がなされてるる。乙れは銭造作業の後の最初 の機械操作であり，そして粗作りされた開いた端部が彈腔の底部から或る一定の長さに切 られる.この理由のために彈腔の底部につき當てられ，そして後に鋸が開いた端部を切斷 することの出來る樣に引达められる 2 つの止め棒を具へてるる。

若し 2 個の止め棒を引込めることが機械作業者の記憶力几依存するとすれば，鋸は開い た端部と一緒に止め棒も切つてしまふといふ危險が伴ふ。更に又, 若し止め棒を進めるて 。とが作業者に依存してるるとすれば, 彈腔の底部に對して, その止め棒は手前でつき當て られることがあり，その場合には彈腔の深さも攵短くなる。乙れ等の困難を除くために， 止め棒は水力によつて操作され，水力垂直萬力と連結して働く。乙の機械は一操作に於て 切られる砲彈の數如何によつて止め棒は 1 つでも 2 つでもよい. 
ての砲彈は水力作用によつて特別の取付具に䋨めつけられ，ての取付具はベッドの上に あるV ブロック及び上部プレス・ブロックから吊下げられたプレス・ブロックとVブロッ クの組合せたものとから出來てるる. 後者は全運動約 $5 / 8$ in. で, 中間片は萬力が開いた

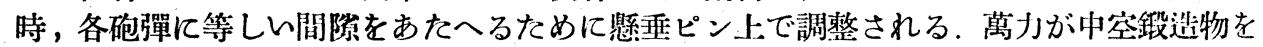

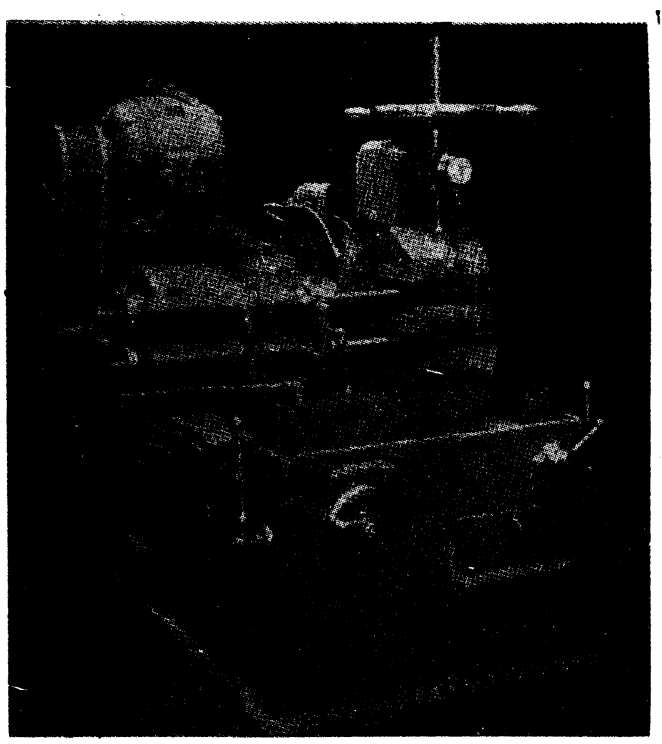

Russell のこぎり機，止め棒を伸した所，

とつかむために開くと共に，止め棒は自動的に全行程進み，かくして鍛造物を一定の位固 に支持する。萬力制御ててが閉鎖位置に動かされると，鉔造物をつかみながら萬力は閉ぢ そして止め棒は自動的に引込められ，かくしててのぎりの州の路には邪廆物がなくなる。

そてでのてぎりのサドルへの水力揆りがかけられる．鋸送りててと萬力制御てては萬力

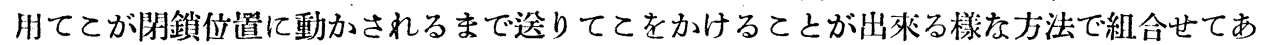
る.

同栐に，のてぎりの揆りが外されるまで, 萬力用ててを開放位置に動かすてとは出來な 几. 止め棒は燒入鋼製の取外しの出來る端部を具へ，それ故止め棒のあて方によつて，異 る深さのものを得るために，端部を長いもの或は短いものと交換するてとが出來る，各々 の場合，彈腔の底部の正しい寸法を得るためて，多少の獨立の調整を要する。

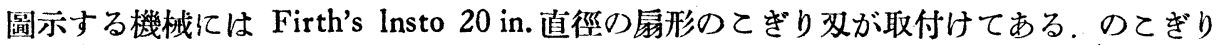
のサドルは，のてぎりの軜への鲌車運轉全部を納めて居り，油壼の中で走つてるる特別に 設計された，高抗張力，熱處理した銅製平蓫車，ダブル・ヘリカル・ギヤを具へてるる. 速度は四通り變へることが出來，切る材料に適する正しい切例速度を選ぶことが出來 る. 高速の軸は球軸受に乘り，のてぎりの軸は砲金軸受で支持されてるる。サドルの頂に

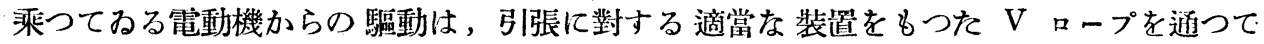
來る。

水力送り機構は電動機驅動で，機械のベッドの中にある。それは特許水力秐り回路を結 合し, サドルへの送りは 1 秒につき 0 から 12 まで無段階に變へるてとが出來る。すべて の制御は中央に集められ，機械の動をと制御は簡單で手輕であるから女子勞働者でるたや すく操作出來る.

原漖 Russell Hydrofeed Duplex Shell Sawing Machine, Machinery Aug. 7, 1941. 罯者 橫田 